\title{
The Master's Tools Revisited: Can Law Contribute to Ending Violence Against Women?
}

\section{Chris Hunter}

For the master's tools will never dismantle the master's house. They may allow us temporarily to beat him at his own game, but they will never enable us to bring about genuine change. Audre Lorde (1984: 112)

\begin{abstract}
1 Introduction
Current development practice prioritises, in fact virtually equates itself with, poverty reduction. However, I have come to the study and practice of development from a background as a feminist activist and practitioner, and as such I am motivated by my interest in reducing inequalities, in particular those that affect women.
\end{abstract}

Once development is framed in terms of inequality, it is difficult to avoid recognising that the changes needed to address the problem include shifting power relations. Violence against women is a case in point. In many historical and cultural contexts, sexual assault or physical violence against a woman by her husband has been understood as a 'normal' aspect of male-female relationships, only problematic if the resulting harm exceeded certain limits or affected public space or another man's woman. In recent decades, women and anti-violence advocates have succeeded in putting violence against women on the agenda of governments and development agencies. As a result it is now likely to be branded as unacceptable, at least in law and official public discourse. There is less consensus on the causes of violence against women. It is sometimes understood as a problem arising from criminal elements in society, individual or family dysfunction or an outcome of male frustration. These explanations frame violence against women as an isolated dynamic, attributable to individual or group deficits. In contrast, feminist accounts view violence against women as an outcome of inequality between the sexes and a mechanism for the ongoing subjugation of women. 'Wife-beating is, therefore, not an individual, isolated, or aberrant act, but a social license, a duty or sign of masculinity, deeply ingrained in culture, widely practiced, denied and completely or largely immune from legal sanction' (Copelon 1994: 132).

From that perspective, ending violence against women means changing gendered power relations. By this, I do not mean just shifting the balance of power between individual men and women, although clearly change is also needed at that level. Rather, I am referring to changing the socially constituted relations between women and men, which are embedded in, and reproduced through, social institutions (see also Harris, this IDS Bulletin).

Having acknowledged violence against women as a problem, a wide range of national governments, international bodies and civil society organisations have released reports analysing the issue and exploring solutions. Most of these reports recommend a range of legal reforms, including specialised national legislation such as domestic violence laws. ${ }^{1}$

From one perspective, reliance on law to prevent violence is illogical: the punitive or protective powers of legislation can only address violence that has already happened and in so doing limit the possibility of further violence by a specific man in the short term. However, considered from the perspective of power theory, law may be a valuable resource for social change. Haugaard's (2003) theory is particularly useful for reflecting on social change that aims to transform power relations. Although he does 
not directly address law, his framework outlining the mechanisms through which power is created, sustained and challenged, can help elucidate the role of law in social change.

Six of Haugaard's modes of power creation focus on social power, 'the added capacity for action which actors gain from society' and which 'derives from social order' (Haugaard 2003: 90). Law fits within several of these: as a mechanism for codifying agreed-on structures (strengthening the predictability which underlies Haugaard's first mode of power creation); as a way of reifying structures or practices and thereby rendering them less vulnerable to challenge; ${ }^{2}$ and as disciplinary power. Haugaard also describes how the state (in his example monarchs) can promote a change in social order by establishing new standards and then validating those who act accordingly. Law is an obvious method for the modern state to create and enforce new structures.

Coercive power is the seventh mode discussed by Haugaard. He argues that physical power or coercion is not the ultimate power (as suggested by Weber and others), but instead takes the Arendtian perspective that the exercise of violence represents the failure of social power. While this distinction may help us to understand power as exercised through war or tyranny, I argue in a later section that recognition of the role of violence against women in sustaining gender relations, and the role of gender relations as a foundation of the social order, suggests more complex links between coercion and social power.

An investigation of legal strategies to address violence against women allows an examination of the multi-faceted interactions between power, social change and gender relations. This article draws on research into the development and implementation of domestic violence laws in South Africa to consider different ways that law may contribute (or not) to transforming gendered power relations and addressing violence against women. I begin with a brief history of legal activism on domestic violence in South Africa and then discuss how law served as a catalyst for social action on violence against women and gender equality more broadly. The second half of the article explores two disparate ways that women may use law: as a source of power over violent men, or to draw on entitlements formalised in law to increase their power to act in their own interests as women. These different approaches - which may coexist in the same organisation or even in the same strategic intervention - demonstrate different understandings of power, reveal some of the complex relations between power and social change, and may help us rethink whether the master's tools can help us to dismantle the master's house.

\section{Domestic violence law in South Africa ${ }^{3}$}

Violence against women, gender relations and women's activism must be understood in their historical and cultural contexts. The complex history of colonial and apartheid South Africa, and women's resistance and struggle under those regimes, have been documented by Bozzoli (1983), Ramphele and Boonzaier (1988) and Walker (1991). Although I do not have space to explore that history here, I want to acknowledge that the particular mix of legislated oppression, economic exploitation and violence which fractured South African society along lines of race, class and gender affects the extent to which lessons can be applied elsewhere. However, the struggle for domestic violence legislation in South Africa provides important insights into women's legal activism. Women successfully advocated for legislation under two radically different political regimes, and the differences and similarities in struggles and outcomes are informative. Second, post-apartheid South Africa has one of the strongest rights-based legal frameworks in the world, creating optimal legal conditions for domestic violence legislation. The failures of law in this context may therefore point to flaws in law as a tool for addressing violence against women. Finally, although the nature and extent of oppression in South Africa may be unique, the resulting 'patchwork quilt of patriarchies'4 emphasises how women's identities and opportunities are constructed through social relations of gender, but also through their experience of race, class, ethnic location, sexuality, disability and geography. The challenges of mobilising across these barriers, and working to change complex power relations, holds useful lessons on the importance of recognising and addressing the diversity among women in any context.

In South Africa there was little public acknowledgement of violence against women and even less action by government prior to the mid1970s. A rape law had been passed in 1957, recognising only 'sexual intercourse without consent' and only outside of marriage. Physical abuse of 
women by husbands (or other family members) was technically covered by criminal laws of assault but what occurred in the household was generally considered a private affair and few men were charged for assaulting family members.

This invisibility of the violence experienced by women was challenged when groups of (predominantly white) South African women, inspired by radical feminists in the West, came together to address rape and other forms of violence against women. ${ }^{5}$ Motivated both by the immediate practical needs of women and by a political commitment to transforming gendered power relations, they campaigned to get violence against women on the public agenda, to challenge societal misperceptions about rape, and to demand better service from the justice system.

Over the next few years, the need to address the material conditions of abused women, and their revictimisation by the justice system, facilitated alliances between these feminist anti-violence advocates and more conservative women's groups. These conservative organisations were not necessarily interested in challenging male dominance or opposing the government but they were concerned with improving women's living conditions. This early activism on domestic violence was one of the first examples of South African women mobilising across political divides to address women's gender interests. By the early 1980s, there was 'considerable lobbying' for legislation that specifically addressed domestic violence, and the alliance with more reformist groups was providing dedicated rape crisis organisations with 'a platform to engage the state' (Meintjes 2003: 146).

This loose coalition remained largely white and middle class until the late 80s. Under apartheid, most politically active black women prioritised the struggle for national liberation (Maitse with Marchbank 2000: 210). Black women were also reluctant to confront the issue of violence by men in their own communities and engage in advocacy that was perceived as likely to further harm black families. Apartheid had torn families apart (through its harsh pass law system, the establishment of homelands as labour reserves, the economic necessity to migrate and unprovoked police violence and harassment) and the right to return to 'traditional' family structures was a rallying cry for the liberation struggle.
Advocacy for laws that would further government and police intrusion into families was unlikely to mobilise poor, black women.

The racial split among women also reflected divergent ideologies that had evolved from different experiences of oppression. Women's subjective understanding of their position, their interpretation of patriarchy and their beliefs about the changes required to overcome oppression varied, as did the alliances that they saw as essential to achieving their goals. Hence, black women remained affiliated with their families and fought alongside black men to challenge the racist, and sexist, apartheid regime, while white women from across the political spectrum worked with the state to challenge men.

These divisions were weakened in the second half of the 1980s, when a growing awareness of the gendered character of political violence directed at black women led Rape Crisis, one of the feminist groups, to expand their understanding of patriarchy. The recognition that 'the white state, not the Black male or the family unit, was for many Black women the primary patriarchal enemy' (Kemp et al. 1995: 140) shifted their perspective, motivated them to join the anti-apartheid struggle and over time resulted in a more multiracial membership. By the late 1980s, new women's organisations also emerged to address domestic violence and rape in Indian, coloured and black areas.

The growing political awareness of domestic violence and women's continued lobby for legislation led to the proclamation of the Prevention of Family Violence Act in 1993. The Act was a breakthrough in that it offered legal recognition of domestic violence and marital rape, albeit in a civil statute. However, many women's groups considered it inadequate, with its narrow definition of domestic violence and minimal protection to those women who came within its ambit. Passage of the bill was also perceived as political opportunism by the National Party who, facing a democratic election after decades of legislated inequality and brutal repression, hoped to repair their image and attract women voters. Despite these controversies, the passage of the Act represented an achievement of women's advocacy and paved the way for further social action.

With the legal recognition of the ANC and other political movements in 1990 there was an upsurge in 
women's activism. During the transition to democracy, women built new coalitions and mobilised to ensure that they would be represented, and gender oppression would be addressed, in all aspects of the transformation of the state. This collective organising across divides of class, race, culture and geography represented a major shift that was critical to ensuring women were not left behind in the new South Africa (Bazilli 1991). Awareness of how women had fared in the outcome of other liberation struggles was one catalyst for women to focus on their interests as women (and not just as members of the black community or working class). As well, the processes and structures established to guide the transition to democracy, which initially excluded women and failed to address gender concerns, provided a target for women's activism that was relevant across divides of ideology and identity. However, there are also indications that women's anti-violence activism had already begun to break down some barriers of race, class and politics and help build the gender consciousness that fuelled this organising. The most compelling evidence of this is found in the equality rights section of the constitution. Women fought for, and won, the constitutional recognition of the right 'to be free from all forms of violence from either public or private sources' (Constitution, Section 12(1)(c), emphasis added). ${ }^{6}$

Advocacy for new legislation that would address the weaknesses of the 1993 Act benefited from the gains women had made through two decades of anti-violence activism, their role during the transition and women's expanded influence with the state. The newly elected ANC government committed itself to introduce an improved domestic violence bill in its first term. As had occurred in the 1970s, women of different political affiliations mobilised to influence the legislation. New links were forged between rural and urban women, and alliances developed between women in civil society and the state.

Yet despite a sympathetic government, a rightsbased constitution, and women's participation in the legislative process, legal reform efforts encountered delays and obstacles. In the end, the Chair of the Parliamentary Justice Committee sided with the women's lobby, overruling an attempt by the South African Law Commission to weaken the draft bill.? The Domestic Violence Act (DVA), passed in December 1998, marked 'a distinctive shift in South African law in that violence against women has been defined and reflected in law as it is experienced by women' (Artz 2001: 5) and it remains one of the best examples of this type of legislation.

Having achieved superior legislation, women had to mount another national campaign to demand implementation of the Act and to challenge their exclusion from the development of the policies, procedures and training essential to effective enforcement. The campaign was successful, forcing the government to keep pressure on staff in the legal system, raising public awareness of the law, and positioning women as citizens demanding access to a resource that the legal system is obligated to provide.

\section{Law and social action}

In South Africa, the work on law and violence against women has been notable for mobilising women across political divides in the late 1970s, building alliances between women in civil society and the state post-1994, and eventually helping to bridge gaps of race and class. Women were able to use this collective strength to advocate for legislation and influence other political developments in postapartheid South Africa. What explains the mobilising power of legal advocacy on violence against women?

First, the focus on women's lived experience and practical needs is of interest to women of diverse political perspectives including groups motivated by charity towards vulnerable populations. The feminists description of the re-victimisation that women experienced in the legal system was as compelling for groups concerned about the needs of abused women as it was for those who believed that the police and courts were part of a 'justice' system.

A second reason that women coalesce around legal reform may be a shared interest in addressing women's marginalisation in law. Hassim, a South African feminist scholar, speculates that 'the most stable interest that cuts across the range of differences between women is their exclusion ... from the political arena' (Hassim 2005). Similarly, the failure of law to recognise and address women's realities may bridge ideological and social differences among women.

Finally, legal strategies are appealing as an accessible approach to an extremely difficult issue. Given the context of endemic violence against women, it is probable that violence has affected most of the 
activists as well as the women they seek to help. Women who want to challenge violence may face physical dangers of retaliation and, perhaps more critically, the emotional cost of recognising the 'degree and meaning of the hatred directed towards [women] - often by men known and/or cared for' (Bennett 2001: 93). To deal directly with violence within the family is to acknowledge a profound violation of rights that is woven into complex relationships built around custom, economic dependence, love and joint responsibilities. Legislation, in defining the problem as having a legal solution and in focusing on individuals rather than widespread oppression or collective harm, allows activists to distance themselves. In addition, as highlighted in the following discussion of law as social control, legal reform creates opportunities to intervene while doing 'little to alter the power relations that remain intact' (Smart 1989: 144).

Working collectively, and building a consensus that issues previously ignored should be recognised and addressed, is an important step in changing the social order (Haugaard 2003: 95). Another critical process highlighted by Haugaard and discussed in the literature on women's empowerment is a change in consciousness, or as Haugaard describes it, a process of bringing tacit knowledge into discursive consciousness, which enables individuals to examine how structures, which they had previously accepted, not only work to their disadvantage but are possible to reject.

The history of South African women's anti-violence activism suggests that the debates around domestic violence facilitated this process, contributing to the development of what Hassim and Gouws call 'a political consciousness of gender' (Hassim and Gouws 1998: 58). During the lobby for the first legislation, controversies arose over the role of the family in perpetuating or addressing domestic violence. Some of the more conservative women prioritised support for the family and lobbied (successfully) for the establishment of a Family Advocate's Office to deal with intimate family violence. Feminist groups challenged this approach, arguing for 'a critical appraisal of the rights of the family in the context of women's oppression' and warning that 'protecting the family would entrench women's subordination' (Meintjes 2003: 148). However, as mentioned earlier, black women involved in the nationalist struggle saw the family as the site of resistance and strength and their perspective encouraged some feminist groups to develop a new understanding of how race and gender intersect in different patriarchal orders. These debates led women to challenge many previously unquestioned assumptions about race, power and 'traditional' structures such as the family.

In summary, legal activism was a catalyst for mobilising South African women from diverse backgrounds and facilitating the development of an autonomous women's movement. Within this movement, discussions of legislation and violence against women raised awareness of how different forces interact to sustain the subjugation of women and condone violence. These developments strengthened women's capacity to participate in the transition to democracy and to demand that strategic gender interests be addressed in political processes and in the new legal framework. The later decision of the Chair of the Justice Committee to accept recommendations of women's organisations over those of the South African Law Commission suggests a shift in power relations within the state.

Clearly the fight for domestic violence legislation was a catalyst for women's social action, and it did contribute to some changes. However, the question remains as to whether the legal reforms achieved in this struggle can contribute to ending violence against women.

\section{Law as social control}

One of the most commonly understood roles of law is as a method of social control, a way to discourage antisocial acts as 'a prerequisite of social order' (Snider 1998: 13). In Haugaard's theory, power is an outcome of the creation of social order and therefore, to the extent that law upholds social order, it can be understood to contribute to 'relations of power and powerlessness' but also to confer on actors 'a capacity for social action which enables them to make things happen which would not otherwise occur' (Haugaard 2003: 88).

However, law is only one of many structures which create and defend social order. The shared systems of thought which underlie the social order are promoted through socialisation and sustained through religious and cultural structures, community norms and socioeconomic forces among others. In many countries, including South Africa, these more 
informal structures of social control may implicitly condone, or even encourage, some degree of violence against women. Law as a formal mechanism of control is therefore competing with cultural beliefs and other social norms that are at best ambivalent, and at worst supportive of woman abuse.

In this context, feminist interest in harnessing 'state power as a counterbalance to patriarchal power in the private sphere' is hardly surprising (Snider 1998: 14), but it raises several dilemmas.

Traditionally, law's concern has been primarily with maintaining social order in the public sphere; as long as 'private' actions do not affect the community, state intervention has been considered unnecessary. As a result, men's violence against their wives (or other family members) has always been treated differently from 'real' assault, which is understood to occur between strangers in public spaces or as a result of criminal intrusion into a private space. As Green notes, legal action is seldom taken against violent husbands unless 'the domestic abuse exceeds certain tacit limits or when this "private" behaviour becomes a public nuisance' (Green 1999: 112). ${ }^{8}$

In fact, it can be argued that the bargain underlying the modern state is that men agree to the state's right to set and enforce certain rules in the public sphere in return for full control in private domains (Pateman 1989). The demarcation of the private from the public and the conditions which make a man's home his castle are created through a body of laws and regulations. Maitse describes how this patriarchal bargain was implicit in apartheid, positioning African men as an extension of the state, 'because while the state oppressed all people in public, the men were legally empowered to oppress and exploit women in private for their own and the state's maintenance of hierarchical and oppressive patriarchal structures' (Maitse with Marchbank 2000: 201; see also Bozzoli 1983)

Domestic violence law therefore operates in a context in which various forms of social control, some of which perpetuate women's inequality and oppression, coexist and intersect.

\subsection{Violence against women - a form of social control}

Feminists have long argued that violence against women is a means of social control through which men, individually and collectively, uphold their dominant position in the family and the community.

Although not all women are directly subjected to abuse, most women do live with a tacit awareness of their vulnerability to male violence (Radford and Stanko 1996). The resulting fear, and the necessity of taking precautions, exerts a controlling influence on most aspects of women's lives. Jones discusses the impact of violence on women's ability to act as citizens, suggesting that sexual harassment is an example of 'a political strategy designed to structure public space in ways that endanger women, hampering or precluding their mobility and regulating the extent to which they can be present in public' (Jones 1990: 786). In Haugaard's terms, this can be understood as a process of structural constraint. When women enter into 'traditionally' male arenas they cannot expect to be 'confirmed' as having a right to that role or space. Rather, they can expect treatment that will diminish their credibility or even threaten them.

Violence may also be a penalty imposed on women who, through their choices or achievements, are perceived as threatening male dominance. For example, in South Africa the phenomena of 'jackrolling', also described as 'recreational gang rape' (BBC 1999), was practised by young men who had dropped out of school and were unable to find jobs. They abducted and raped schoolgirls in the hope of impregnating them and therefore ending their education (JMCIQLSW 2002). This corresponds to the 'disciplinary power' discussed by Haugaard, and demonstrates how violence may reflect both a failure of social power and a method of reproducing the social order. The young male gang members lack the social power to shape gender relations and women's roles through institutional means - for example through the education system or as husbands or fathers - and so respond with violence to what is perceived as a threat to the current distribution of power. The outcome of this sort of violence however, is to confirm the social order by confirming that women who threaten male dominance are exposing themselves to violence. As Haugaard notes, discipline is effective to the extent that 'routines are reified or internalized as practical consciousness knowledge' as a result (Haugaard 2003: 107).

Consideration of violence against women as a mechanism of producing and reproducing the social 
order challenges Haugaard's contention that coercive power is not only different from social power, but in fact reflects a failure of that power. MacKinnon, discussing how violence against women benefits all men, argues that behind other forms of male power, such as the power men exercise in law, is the threat of coercion through sheer physical force. Her argument is not that all men use physical violence against women, but that violence and the threat of violence are obstacles to women's equal participation in society, and that men 'as a group benefit from these same arrangements by which women are deprived' (MacKinnon 1989: 93). Haugaard

characterises social power as that produced 'through the recreation of social order when the king's sword is firmly in the scabbard' (Haugaard 2003: 88). However, the awareness of the sword and the ease with which it can be drawn for use underpins the power granted to the king through social consensus and sustained through social mechanisms including law.

It can also be argued that the family as a social structure is sustained through violence. As Freeman observes, 'violence by husbands against wives should not be seen as a breakdown in the social order so much as an affirmation of a particular sort of social order, namely a patriarchal one' (1980: 216). Many husbands do not need to use violence to benefit from it as women are often socialised to subordinate themselves to men. 'There is no need to rely on might when control is reinforced through deference' (Freeman 1980: 224).

\subsection{The family as social control}

The family plays a critical role in perpetuating the social order through socialisation. Haugaard's third mode of power creation is the development of 'social consciousness which sustains structural practices' (Haugaard 2003: 87). Through socialisation, people internalise societal norms, develop the selfdiscipline to avoid behaviour that they understand as antisocial, and acquire an understanding of appropriate gender roles (Snider 1998). Families also exercise culturally specific methods of social control. Within African families, Ramphele and Boonzaier suggest that male control 'stretches from the cradle to the grave. The father's control operates up to the time of marriage, at which point it passes over to the husband' (1988: 156). They identify lobola or bridewealth as a 'corner stone of this ideology of control ... which is used to secure control over the reproductive powers of the woman' and to symbolise 'the transfer of control over individual women from one patriarchal family structure to another'.

Families also develop beliefs about the use of violence and power. A comprehensive survey on violence against women by Statistics Canada found 'considerable evidence' that witnessing the abuse of their mother increased the likelihood that boys would become abusive men and that girls would become victims (Johnson 1998). From the perspective of Haugaard's framework, 'systems of thought sustain conditions of possibility', thus early socialisation makes certain responses to actions or circumstances more likely and precludes others (Haugaard 2003: 98).

Consideration of the role of socialising in maintaining current power relations demonstrates that women are actors as well as victims within families and helps to avoid 'over-intentionalising social order in the form of a conspiracy theory' (Haugaard 2003: 105). 'Mothering is (among other things) a controlling role, whereby children learn to conform, restrain antisocial impulses, and accommodate the discipline demanded of contributing adults in that society' (Snider 1998: 14). This recognition of family as a site of both relative power and subordination for women is important to an understanding of gender relations, violence and women's advocacy (or lack of) on behalf of themselves and others.

Maitse describes how, during the struggle for national liberation, the family both idealised African women and contributed to maintaining unequal power between women and men:

On the one hand, the family was a haven from the harsh brutalities of apartheid, and a site to inculcate and imbibe cultural values. Women became transmitters and emblems of African cultural norms, while men assumed the position of custodians of that culture. It was within the family that the next generation was taught about beliefs and obligatory customs for the continuation of the African race ... however, political mobilisation was also based on the perception that apartheid was destroying the African family, yet during the struggle for national liberation gender relations were not problematised.

(Maitse with Marchbank 2000: 202) 
Seen this way, the family was not only a mechanism for socialisation that perpetuated patriarchal values, but also the foundation for a new, post-apartheid, social order that dismissed women's issues as subordinate to pressing political issues. This dual role both strengthened the role of the family in social control and made it more impervious to changes that would render it safer for women.

\subsection{Intersecting systems of social control}

As suggested earlier, the creation of the family as a private domain is fundamental to all modern states. $A$ study of the gender politics of 'single-sex' hostels in the Western Cape demonstrates how state regulations interacted with 'traditional' structures to produce and maintain women's subordination. According to Ramphele and Boonzaier, the hostels were a 'logical outcome' of government policies to 'discourage urbanisation of Africans' (Ramphele and Boonzaier 1988: 157). Hostels provided temporary housing for male migrant workers only, making women's access to hostel facilities dependent on relationships with their husbands (or other men) that were registered bedholders. Given the acute shortage of urban housing, this placed men 'in an enormously powerful position over women, making the hostels truly 'a man's world' (Ramphele and Boonzaier 1988: 158). Male power was manifested in women's exclusion from community decision making and their complete responsibility for domestic work, as well as through physical and sexual violence. Assaults occurring in shared space might result in a fine for 'disturbing the peace' (levied by men elected to govern the community); however, a man could beat a woman in the open veld without penalty.

Women's dependence fostered submissive behaviour and made them unwilling to question men's decisions. This reinforced the stereotype of women as indecisive and 'lacking the capacity for rational thought' (Ramphele and Boonzaier 1988: 159), which in turn justified men's authoritarian decisionmaking..$^{10}$ The study also describes how 'tradition', as a 'reconstruction of the past that is unchallengeable' was used to support the system of male dominance. Thus, government policies created the conditions in which men exercised control over their wives (and other dependent women), justified in part by women's reactions and supported by 'tradition' and community structures.

It is not only authoritarian states that shape family and household structures. Freeman, writing in the
British context, documents how tax law, social welfare regulations and family law 'impose particular structural forms on social relationships both within and without the family' and in doing so reproduce 'an ideology about the family that not only makes violence against women understandable but almost makes it necessary' (Freeman 1980: 216). His argument is that by reinforcing women's economic dependence on men, creating obstacles for single women and ensuring that divorce entails significant risks, law places women in a subordinate position therefore making violence against women 'meaningful ... [as] a mechanism of social control' (1980: 238). Freeman concludes that the priority for feminist legal reform is to dismantle the ways that the law continues to shape gender relations based on male dominance, rather than seeking legal remedies for battered women (1980: 240-1).

Although some of that dismantling may have happened since 1980, the importance of the family as 'a complementary institution to the state,' ensures that there will be other social forces with an interest to 'distort, impede, or prevent' change in family roles and relationships (Fineman 1994: xv). Within South Africa, although the new rights-based constitution has removed many forms of legal discrimination and taken positive steps to uphold women's rights (for example by legalising abortion), feminists report that these gains 'have not in any significant way challenged male domination' in the families or communities."

The interest of states in sustaining the social order, and therefore in maintaining families (and gender relations) as currently structured, may explain the reluctance of governments to address domestic violence. Despite differences in family structures, gender ideologies and political regimes, national governments commonly give priority to keeping the family together, even (or often) at the expense of women's rights and safety.

Rajan offers an insightful analysis of the political compromise between the Indian government's interest in protecting families (but being seen to uphold women's rights) and feminists' demands that it address domestic violence:

We have a situation in which the state seeks to preserve the family even while conceding rights to married women; while feminist activists fight 
to protect women's rights even if it means (by not pressing for divorce) looking like preserving the family ... therefore it is the rights of the (still) married woman, specifically in the form of the right to occupy the matrimonial home, that emerges as the narrowly conceived 'solution', even as it severely compromises and curtails both the power relations of the patriarchal family and women's autonomy. (Rajan 2004: 782)

The apartheid government's insistence on preserving the family was exemplified by the establishment of a 'Family Advocate' to lead government action on violence against women. Although the 1998 DVA does not prioritise the family over women, national discourse may, as demonstrated by Jacob Zuma, then Deputy President, speaking to a conference on gender violence: 'Today you meet to discuss the issue of gender violence, an issue so prevalent in our society that it threatens the very centre of our society, the family' (Zuma 1999).12

\subsection{The limitations of the master's tools}

This analysis suggests an irreconcilable dilemma in using the power of law to force a change in the behaviour of violent men. If the modern state is dependent on the preservation of the family, and the family is structured through law and maintained (at least in part) by the continued subordination of women through violence (or the possibility of violence), then the use of law to control violence is fundamentally flawed. Radford and Stanko (1996) argue that government action to criminalise violence against women arises from the need to 'clean up the public face' of heterosexuality and the family:

So by moving towards curbing the excesses of male sexual violence within the family and heterosexuality, these sacred institutions of patriarchy are preserved intact and patriarchal gendered relations are reaffirmed, reproduced and represented as in the best interest of women and children. (Radford and Stanko 1996: 78)

In looking to law, an institution of patriarchy, to counter men's violence against women, feminists are attempting to use the master's tools to dismantle the master's house (Lorde 1984: 112). The problem in using law to assert power over violent men is not just that law may not be as effective as the competing mechanisms of social control. The more difficult issue is that in engaging with the law, feminists are tacitly accepting the significance of a system that is implicated in constructing and sustaining social systems which support violence against women.

\section{Law and empowerment?}

Yet, the South African case study also demonstrates how legal advocacy has contributed to women's empowerment. The galvanising power of domestic violence and the appeal of legal 'solutions' enabled South African women to build links across ideological divides and eventually across entrenched barriers of race and class. Debates among activists encouraged a more critical analysis of gender relations and the intersecting roles of family and state structures in maintaining women's subordination. Collective action by women successfully influenced the commitment to table domestic violence legislation (under apartheid and ANC governments) and ensured that the 1998 DVA addressed women's realities and placed accountability for enforcement on the police.

Women's legal activism also facilitated their entry into the state. The strength and political skills that women gained through legal advocacy helped to propel them into the state as parliamentarians and civil servants. Since the DVA came into effect at the end of 1999, an increasing number of women's organisations from different racial and class communities have joined the earlier activists in monitoring its enforcement. The provisions are being used by women to make claims on the legal system, which remains predominantly male (in personnel and practice). Women's and anti-violence organisations have become players within that system, gaining influence by providing training and establishing community-based committees to coordinate services for abused women and to monitor legal procedures and outcomes. However, this vigilance is a huge drain on activists' resources, diverting energy from other, potentially more transformative, strategies. As well, the urgency of women's immediate needs (for safety, shelter, etc.), the power differentials inherent in the legal system, and the need for continued compromise in order for women to maintain their foothold in that system, tend to keep this engagement focused on improving women's immediate conditions rather than addressing the gendered power inequities evidenced in the continuing failures of legal enforcement. 
Although women's engagement with the law may be unable to dismantle the 'masculine culture' of the law (Smart 1989), or challenge the ways in which law upholds a social order that allows violence against women, legal activism may facilitate a shift in women's self-perceptions and sense of entitlement. Reconstructing the abuse of women as a human rights violation may contribute to a change in women's collective identities.

The constitutional right to freedom from violence in South Africa has been used to frame domestic violence as an abuse of human rights. However, there is little indication that this shift to a rightsbased understanding of domestic violence is widespread. The text of the DVA hints at a link between rights and domestic violence but the implementation of the Act remains mired in attitudes that uphold men's impunity in the household and position women variously as passive victims, unreliable witnesses, or provocateurs.

The more transformative potential of a rights-based approach may be found in stepping outside a limited view of rights as something that can be granted in law, and seeing them instead as 'political and legal resources that may be mobilised to advance gender equality and women's empowerment' (Albertyn 2004: 28). There is a symbolic power vested in the language of rights, which lends legitimacy to claims. 'To couch a claim in terms of rights is a major step towards a recognition of a social wrong ... to claim that an issue is a matter of rights is to give the claim legitimacy ... It is almost as hard to be against rights as it is to be against virtue' (Smart 1989:143).

Furthermore, rights have a legal as well as moral authority, giving rise to obligations on the part of the State and enabling women to reframe their demands from 'the weak, dependent language of needs to the more powerful and assertive language of rights.' As Frances Butegwa, founder of Women in Law and Development in Africa explained in Hodgson (2002): 'Previously ... you were begging ... the state [was] some benevolent entity that you [were] trying to say please, do this. But now the language and politics are different. You are saying they are obliged, they have ratified these things and they have agreed to be bound, so do whatever you say you are going to do' (Hodgson 2002: 10-11).

If rights are 'shaped through actual struggles, informed by people's own understandings of what they are justly entitled to,' as argued by NyamuMusembi (2002: 1), then it may be women's legal advocacy at a national and local level, rather than any change in written law, that will create the right to freedom from violence in the domestic sphere. Meintjes supports this thesis noting that, despite the 'remarkable achievement' of a constitution that promotes substantive equality, 'women will only achieve effective equality once they are able to claim their rights. This is not something individual women are going to be able to do in a society which has not reconstructed its gender power relations' (Meintjes 1998: 83). As women continue to mobilise for legal reform and action to end violence, they recreate themselves as citizens with rights to the equal benefit of the law and security of the person. This struggle, supported by other initiatives aimed at broad change in social attitudes, may be a means through which legal reform contributes to the longterm transformation of gender relations.

\section{Conclusions}

Reliance on law to end violence against women is an attempt to use the master's tools to dismantle the master's house, and as such is limited to improving women's condition without challenging the gendered hierarchy. However, in the act of demanding the protections guaranteed by law, and making the legal system accountable to women, women are claiming their rights and practising citizenship. Women activists challenge social constructions of women as victims, or as complicit in the violence against them, by marching accused rapists to the police station, reviewing police conduct and publicly challenging the failures of the legal system as a whole. In these struggles, women are using law to legitimise a focus on women's rights, and bringing the issue of domestic violence out of the house and into the public domain. In so doing, women's legal activism has the potential to renegotiate the meaning of the domestic sphere and radically change gender relations, thereby contributing to preventing violence against women. 


\section{Notes}

* Thanks are due to Andrea Cornwall, Rosalind Eyben, Colette Harris, Jethro Pettit, Nardia Simpson, Linda Waldman and Lee Webster for helpful comments on earlier drafts of this article.

1 For example, in 1996 the UN Special Rapporteur on Violence Against Women suggested that domestic violence legislation 'is by far the most effective legal mechanism to address the issue' of violence in domestic relationships (para. 129) and recommended that all states enact such legislation (para. 142(d)) (Coomaraswamy 1996).

2 See Smart for a discussion of how law claims to distinguish what is true from what is not, thereby exercising power that manifests in material ways (through legal judgements) and through its 'ability to disqualify other knowledges and experiences' (1989: 11).

3 This history of anti-violence activism in South Africa draws particularly on Albertyn et al. (1999) and Meintjes (2003).

4 Described by Bozzoli in 1983.

5 For example, 'Rape Crisis' was established in Cape Town in 1976 and 'People Opposing Woman Abuse' in Johannesburg in 1979.

6 For a history of the Women's National Coalition, established to ensure that women's voices were heard in the transition to democracy, see Meintjes (1998) and Hassim and Gouws (1998).

\section{References}

Albertyn, C. (2004) Women's Rights, Centre for Applied Legal Studies, www.genderstats.org.za/ documents/Women\%27sRights. pdf (accessed 7 September 2006)

Albertyn, C., Goldblatt, B., Hassim, S., Mbatha, L. and Meintjes, S. (1999) 'Engendering the Political Agenda: A South African Case Study', in International Research and Training Institute for the Advancement of Women (eds), Engendering the Political Agenda: The Role of the State, Women's Organizations and the International Community, www.un-instraw.org/en/ (accessed 7 September 2006)

Artz, L. (2001) 'Policing the Domestic Violence Act: Teething Troubles or System Failure', Agenda 47: 4-13

Bazilli, S. (1991) Putting Women on the Agenda, Braamfontein: Raven Press

BBC News Online (1999) 'Mbeki Condemns Violence Against Women', 10 August, http://newsbbc.co.uk/ 1/hi/world/africa/415436.stm
7 For a description of the struggles to achieve a better domestic violence law, see Meintjes (2003).

8 Although rape has often been seen as a crime, with severe (if seldom imposed) penalties, this is congruent with the inaction on domestic violence: rape has frequently been understood as an act perpetrated by a stranger (or a known enemy) which infringes on a man's exclusive rights over the body of a particular woman and injures that woman's reputation, diminishing her value. It therefore represents a public harm to a (male) member of the community, whether as a property crime or as an insult to the man's honour.

9 By tradition, lobola was the payment of cattle from the father of the groom to the father of the bride, although current lobola exchange is more likely to be monetary.

10 Ramphele and Boonzaier (1988: 161) point out, however, that women were not just passive victims and discuss how women manipulated the system of male dominance to advance their own interests.

11 Sheila Meintjes, personal communication, August 2005.

12 Ironically, Zuma's profile may now have more to do with the circumstances surrounding a charge, and acquittal, of the rape of a family friend.

Bennett, J. (2001) 'Enough Lip Service! Hearing Postcolonial Experience of Gender-based Violence', Agenda 50: 86-96

Bozzoli, B. (1983) 'Marxism, Feminism and South African Studies', Journal of Southern African Studies 9.2: 139-71

Coomaraswamy, R. (1996) Report of the Special Rapporteur on Violence Against Women, its Causes and Consequences, Commission on Human Rights, 52nd session, Item 9(a), UN Document E/CN.4/ 1996/53

Copelon, R. (1994) 'Intimate Terror: Understanding Domestic Violence as Torture', in R. Cook (ed.), Human Rights of Women: National and International Perspectives, Philadelphia: University of Pennsylvania Press

Constitution of the Republic of South Africa (1996) Act 108 of 1996, www. polity.org.za/html/ govdocs/constitution/saconst. html?rebookmark=1 (accessed 7 September 2006) 
Domestic Violence Act (1998) No 116 of 1998, Republic of South Africa

Fineman, M.A. (1994) The Public Nature of Private Violence, London: Routledge

Freeman, M.D.A. (1980) 'Violence Against Women: Does the Legal System Provide Solutions or Itself Constitute the Problem?', British Journal of Law and Society 7: 215-41

Green, D. (1999) Gender Violence in Africa: African Women's Responses, London: Macmillan

Hassim, S. (2005) 'Terms of Engagement: South African Challenges', Feminist Africa 4 , www.feministafrica.org/2level.html (accessed 7 September 2006)

Hassim, S. and Gouws, A. (1998) 'Redefining the Public Space: Women's Organisations, Gender Consciousness and Civil Society in South Africa', Politikon 25.2: 53-76

Haugaard, M. (2003) 'Reflections on Seven Ways of Creating Power', European Journal of Social Theory 6.1: 87-113

Hodgson, D. (2002) ‘Women's Rights as Human Rights: Women in Law and Development in Africa (WiLDAF)', Africa Today 49.2: 2-26

Johnson, H. (1998) 'Rethinking Survey Research on Violence Against Women', in R.E. Dobash and R.P. Dobash (eds), Rethinking Violence Against Women, London: Thousand Oaks and Delhi: Sage: 23-51

JMCIQLSW (Joint Monitoring Committee on the Improvement of Quality of Life and Status of Women) (2002) Report on Violence Against Women, www.polity.org.za/html/govdocs/reports/ $w$ violence/index.html (accessed 8 September 2006)

Jones, K. B. (1990) 'Citizenship in a Women-Friendly Polity', Signs: Journal of Women in Culture and Society 15.4: 781-812

Kemp, A., Madlala, N., Moodley, A. and Salo, E. (1995) 'The Dawn of a New Day: Redefining South African Feminism', in A. Basu (ed.), The Challenge of Local Feminisms: Women's Movements in Global Perspective, Boulder, CO: Westview Press Lorde, A. (1984) Sister Outsider: Essays and Speeches, Berkeley, CA: The Crossing Press

MacKinnon, C. (1989) Towards a Feminist Theory of the State, Cambridge, MA: Harvard University Press Maitse, T. with Marchbank, J. (2000) 'Revealing Silence: Voices from South Africa', in S. Jacobs,
R. Jacobson and J. Marchbank (eds), States of Conflict: Gender, Violence and Resistance, London: Zed Books: 199-214

Meintjes, S. (2003) 'The Politics of Engagement: Women Transforming the Policy Process Domestic Violence Legislation in South Africa', in A.M Goetz and S. Hassim (eds), No Shortcuts to Power: African Women in Politics and Policy Making, London: Zed Books

Meintjes, S. (1998) 'Gender, Nationalism and Transformation: Difference and Commonality in South Africa's Past and Present', in R. Wilford and R.L. Miller (eds), Women, Ethnicity and Nationalism: The Politics of Transition, London: Routledge

Nyamu-Musembi, C. (2002) Towards an Actororiented Perspective on Human Rights, IDS Working Paper 169, Brighton: IDS

Pateman, C. (1989) The Disorder of Women: Democracy, Feminism and Political Theory, Stanford: Stanford University Press

Radford, J. and Stanko, E. (1996) 'Violence Against Women and Children: The Contradictions of Crime Control Under Patriarchy', in M. Hester, L. Kelly and J. Radford (eds), Women, Violence and Male Power, Buckingham: Open University Press

Rajan, R.S. (2004) 'Rethinking Law and Violence: The Domestic Violence (Prevention) Bill in India, 2002', Gender and History 16.3: 769-93

Ramphele, M. and Boonzaier, E. (1988) 'The Position of African Women: Race and Gender in South Africa', in E. Boonzaier and J. Sharp (eds), South African Keywords: The Uses and Abuses of Political Concepts, Cape Town: David Phillip

Smart, C. (1989) Feminism and the Power of Law, London: Routledge

Snider, L. (1998) 'Towards Safer Societies: Punishment, Masculinities and Violence Against Women', The British Journal of Criminology 38: 1-39

Walker, C. (1991) Women and Gender in South Africa to 1945, Cape Town: David Phillip and London: James Currey

Zuma, J.Z. (1999) Address at the Conference on Gender Violence by the Deputy President of the Republic of South Africa. 28 September 1999, www.info.gov.za/ speeches/1999/9910011035a1001.htm (accessed 7 September 2006) 